Magdalena Cieślak*

\title{
“I fear I am not in my perfect mind.” Jan Klata's King Lear and the Crisis of Europe
}

\begin{abstract}
In his Shakespearean productions Jan Klata tends to radically experiment with sets, texts, and contexts. He puts the plays in culturally and politically specific locations, experiments with bi- or multilingual productions, and incorporates other texts into the Shakespearean frame. In this way, he uses Shakespeare as a means to address contemporary problems and tensions that are vital for his geopolitical reality, exploring the issues of national identities, the cultural legacy of Europe and its nations, as well as past conflicts and present crises. Klata's King Lear (Narodowy Teatr Stary, Kraków, 2014), set in the religious context of the Catholic Church and using mostly Polish language, with only decorative additions in foreign languages, does not engage in European politics with the same directness and force as his earlier productions. And yet, as I wish to argue, this performance is also strongly concerned with European identity, and may, therefore, be seen as a valid voice in the discussion on how Shakespearean productions help to understand our current-day reality.
\end{abstract}

Keywords: Jan Klata, King Lear in Poland, Europe, Catholic Church, diversity, unity, identity.

Europe's history is defined by attempts to emerge as a unity out of plurality, and be recognized as a single entity standing united regardless of, and sometimes because of, its diversity. Discussing the early emergence of a European sense of belonging, Andrzej Wicher mentions the religious and political concept of Res Publica Christiana, a term sometimes applied to medieval Europe (104). The idea of European kingdoms united through the rule of Rome dates back to the office of Pope Gregory the Great, who, according to Ullman, called it the "Society of the Christian commonwealth," societas respublicae christianae (qtd. in Wicher 104), but the concept of a community of European Christian states, based on the idea of civitas Christiana, was first put forth in 1306 by Pierre Dubois in De recuperatione terrae sanctae (On the Recovery of the Holy Land). The notion of the community of European states specifically points to

* University of Łódź, Poland. 
Christianity "as Europe's main ideological 'glue', or its uniting factor" (Wicher 104), the common religious identity being believed to create an image of an ideologically united entity. It was of serious political significance especially in the face of military threats, and was used, for example, to negotiate peace conditions with the Grand Khan in mid-thirteenth century. In 1246, Brother John de Plano Carpino ${ }^{1}$ and Benedict the Pole were sent by Pope Innocent IV to the Great Khan with a peace mission. Wicher (105-107) explains how they tried to use the image of a united Europe in foreign politics negotiations, and notes that the emissaries were aware that such mystification was necessary to cover up the fact that Europe was governed by chaos and conflict, as it rendered it a potentially easy prey for the Mongol Empire, a realm that was, by contrast, portrayed as homogeneous. With reference to the medieval context, Wicher (115) stresses that any discourse on identity, national or other, is still fuelled by the desire to "strengthen the emotional bond between the members of a group," a task which is typically achieved by emphasizing similarities at the cost of differences. He also points (105) to the fact that in spite of political pluralitymedieval Europe having been plagued by numerous internal conflicts - the need to create a group identity was readily acknowledged then, even though it did not reflect the actual reality.

The current state of European affairs can be seen as an extension of, and variation on, those desires. Twenty-first-century Europe keeps reimagining itself as a unified entity. Embracing its diversity and plurality, multiculturalism and multilingualism being treated as key aspects of its complex geopolitical, economic and cultural identity, Europe sees itself as a larger body, united by shared past and present interests. History plays a key role in creating today's sense of European identity, and, importantly, Christianity remains one of its vital elements. Another feature of Europe's shared heritage is Shakespeare. An icon of Western literature and culture, "Shakespeare" is used to solidify the cultural identity of contemporary Europe. The very nature of scholarly organizations such as the European Shakespeare Research Association (ESRA), and events such as international conferences or projects, suggest that Europeans assume they have common interests, and tend to seek platforms to develop them. Celebrating the diversity of voices in a variety of communication networks, Europeans continue to assert the need to celebrate the sense of belonging. In the past, the desires to seek connecting voices were motivated by dramatic and immediate political necessities, and one wonders to what extent the continuity of those desires is fuelled by similar anxieties. In the face of such troubles as the growth of local nationalisms, Brexit being one of the consequences, or reactions to terrorist threats and waves of refugees, Europe's identity as based on and respecting a sense of community may be seen as being in danger, and therefore

${ }^{1}$ Other spellings of the name include John of Plano Carpini and Pian del Carpine. 
in need of addressing. In this paper, Jan Klata's 2014 King Lear is discussed as a performance that, like his other Shakespearean productions, is strongly concerned with the European cultural legacy and identity, and may be seen as a valid voice that addresses current problems and tensions in our immediate geopolitical reality.

Jan Klata's Shakespearean productions engage in provocative ways with the issues of Europe's diversity, and presenting multilingual and multicultural experiences they suggest the underlying desire to communicate values assumed to be shared. His strategy differs from other directors' uses of heteroglossia in productions such as Karin Beier's 1995 A Midsummer Night's Dream or 1997 Tempest, in which differences, discontinuity and misunderstandings were accepted or even, as Carlson (159) claims, glorified in a postmodern vein. Klata's multilingual productions also frequently emphasize linguistic and cultural diversities as a source of miscommunication, as in Titus Andronicus in 2012, in which linguistic misunderstandings, as well as cultural prejudices and stereotypes, were used to comic effects. ${ }^{2}$ Such diversities, however, in both Titus Andronicus and Klata's other Shakespearean productions, are ultimately explored as platforms for discussing international relations. Those relations, frequently originating in conflicts from the past, serve to expose the tensions of the present, and provide a strong sense of continuity as well as illustrate the desire to communicate. Through the medium of the theatre-the experience of actors working together and of various audiences watching the productions in different places - those dialogues and tensions may lead to a mutual understanding, and help to see Europe and the world as a place of shared experiences not in spite of but in its diversity. ${ }^{3}$

Unlike the significantly Polish/German Titus Andronicus, ${ }^{4}$ or the German/ Polish/English Hamlet, ${ }^{5}$ King Lear, a 2014 production at Teatr Stary in Kraków, does not engage in European politics with the same directness and force as Klata's earlier productions. ${ }^{6}$ Importantly, it is not a multilingual production. It is performed almost exclusively in Polish, with occasional interventions in other languages that appear to be purely decorative. The first lines to be heard in the production, however - the lyrics of a song to the opening scene - are in a foreign language. As is typical of Klata's productions, the musical opening is highly theatrical and carefully choreographed. Lear, dressed in papal vestments, is sitting on a stylized throne, which is carried onto the stage by several men in red

\footnotetext{
2 See Mancewicz.

3 For a more detailed analysis of the various strategies in Klata's multilingual productions see Cieślak, "“... the ruins of Europe"”.

4 In Teatr Polski in Wrocław and Staatsschauspiel Dresden, premiered in September 2012.

5 In Shauschpielhaus Bochum, premiered in March 2013.

${ }^{6}$ For a detailed analysis of the production see Cieślak, "King Lear".
} 
robes. As Lear is being brought downstage, eight priests in plain black robes, their backs to the audience, perform a reverential dance: they approach Lear one by one, bow and retreat into the row. ${ }^{7}$ This introduction to the world of the Catholic Church is performed to a cover version of Prince/Sinéad O'Connor's famous "Nothing Compares 2 U," entitled "Shanzhai". It is performed by Fatima Al Qadiri, and is sang in a meaningless stream of mock-Mandarin ("Hyperdub release"), except for the repetition of the word "shanzhai", connoting fake brands and smuggled goods.

Another equally mysterious language is used during the scene on the heath (3.1) involving Lear, Kent, the Fool and Poor Tom. The heath is represented by a transparent cage-like plastic box, which descends from above and traps Lear. Kent chooses to stay inside with him, and then the Fool and Poor Tom join them. During the storm scene, to music and strobe lights, the demonlike Fool, dressed in black papal vestments and a mitre, screams and howls incomprehensibly, and then dances inside the "cage". In his fake performance of madness, Poor Tom bangs his hands on the cage, then jumps on top of it, and, as if having a fit, starts "speaking in tongues". What he actually says is the Lord's Prayer in Aramaic, a cultural text that for an acute viewer may become recognizable in the context of the Catholic setting, even if it is spoken in an archaic language.

The use of those diverse languages is subtle, and may seem only ornamental, but is, in fact, symbolic, and can be understood as an allusion to the significance of the linguistic and cultural diversity of the roots of Europe's identity. Aramaic, one of the biblical languages, is the language of Christianity, a religion that provided the ideological basis on which the new Europe was built after the fall of the Roman empire. Ironically, however, it is not a European, but an Afro-asiatic, language. What is more, the area where it used to be spoken is now a site of political and religious struggles that significantly affect European, as well as global, politics. A serious phase of the current European migrant crisis started a few years ago with a wave of refugees from Syria and Iraq, the territories where Aramaic used to be spoken countries ago. The mock-Chinese of Fatima Al Qadiri's "Shanzhai", in turn, can be seen as an allusion to the economic power of Asia, and the ways in which it affects Europe. On the one hand, dynamic and accommodating Asian manufacturers help to fuel the wellbeing of Europe's economy by producing goods at very low rates that

${ }^{7}$ All characters in the production are priests and cardinals and are understood as male, including Lear's daughters. However, while Goneril and Regan are played by men, Cordelia is the only character played by a woman, Jaśmina Polak, and she also plays the Fool, dressed in a mock-papal black costume. Although the Fool may evoke associations with Pope Joan, the legendary "heresy" at the heart of the Catholic Church, the production does not treat Cordelia or the Fool as female. 
European labels sell for much higher prices. On the other hand, the European market is also flooded with cheaper alternatives from Asia that come to Europe through various channels. As direct online purchase and delivery are now increasingly popular, European companies are easily bypassed, and recognizable local labels have to compete with "shanzhai". Fatima Al Qadiri's cover version, in itself an alternative of an existing musical "label", reflects a financially and ideologically problematic dilemma currently faced by Western markets.

Those rare moments of linguistic distractions, however, are located in an otherwise homogenous environment, as the production is set in the heart of the Catholic Church. Lear is presented as the pope, and all the other characters as priests, including Lear's daughters - the daughters of the Church. Klata, justifying that choice, says that he was looking for a contemporary equivalent of absolute monarchical authority, understood as divine, never to be questioned or transferred. At the same time, the Catholic Church can also be seen as the basis on which Europe is alleged to be built. The vestiges of the medieval Res Publica Christiana, with Rome at its center, are invoked to represent a certain European heritage, with its common system of values. Finally, King Lear being the study of an aging and deteriorating mind, an identity falling apart as it struggles with its own weakness, can also be interpreted as a symbolic comment on Europe, whose integrity and unity is weakening. Considering the production premiered in December 2014, these allusions cannot be taken as commenting on the recent crises affecting the EU, such as the terrorist threat, record influx of refugees, and Brexit. However, the predicaments encountered by other ailing member states provided enough warning signs to make the production look both prophetic and relevant. Lear, motivated by what he believes to be sensible and just at the time, makes decisions whose consequences he cannot predict. The kingdom's division eventually destroys the kingdom, as well as Lear himself.

There are two focal points in Klata's production: one is the study of Lear's weakness, age and dementia; the other is the vision of a catastrophe resulting from the fall of authority — royal and ideological — that is believed to be absolute and divine. Lear's weakness, both physical and mental, is highlighted by the fact that throughout the performance he is carried or pushed in his wheelchair-like throne. Then, after the confrontation with Goneril and Regan in 2.4, a bare intensive care bed is brought in, and Lear is placed in it. This moment of incapacitation is very moving, as Goneril and Regan put up the bed's railings and fiddle with the remote control to adjust the position of the bed, while Lear lies in it, motionless. Lear walks by himself only twice. First, he manages to get out of bed for the mock-trial of Goneril and Regan (3.6), but his power is only mobilized for a fleeting moment. Quickly realizing the futility of his action, Lear retreats to his bed. The other instance of Lear's mobility is powerfully used at the end of the production. Significantly in the light of Klata's thematic focus, the performance ends on Lear's death, omitting Cordelia's return, her reconciliation 
with Lear, and their tragic death. The final sequence shows Lear surrounded by all the characters who appear to have returned to their initial, subservient role. He admits: "I am a very foolish, fond old man [...] I fear I am not in my perfect mind" (4.6.53-56). He then walks away-unassisted-from the stage while the others, singing a Polish equivalent of "For He's a Jolly Good Fellow" ("Sto lat"), do not seem to notice his departure at all. As the scene shifts from what initially seems to be a birthday celebration into an odd end-of-life ritual, all the priests wave upwards, as if saluting Lear's departing soul. Thus-with a physically weakening Lear, and with such an ending - the production specifically records Lear's last journey, and the struggle of a failing body before it finally gives in to death.

Following the death of Jerzy Grałek, the actor playing Lear, in February 2016 , the production went on. Lear's physical presence was replaced by prerecorded audio fragments of Grałek's previous performances of Lear. The throne and the bed are still in the production to delineate the space Grałek/Lear occupied, and the other actors perform as if Grałek were on stage. But the audience cannot see Lear, only hear his voice. As Lear is now literally a disembodied mind and voice, this change has emphasized his mental weakness and the deterioration of his identity. Interestingly, before the performance begins, a slightly blurred image of Grałek/Lear's face is projected on the curtain. That face, deliberately a little out of focus, confronts the spectators as they are taking their seats. Thus, when the curtain rises, the performance appears to take the audience inside Lear's head. Without Grałek, the production no longer portrays Lear's physical weakness, but relies on his ephemeral presence, and appears to be exploring the fantasies of the disintegrating, haunted and tormented mind of a person who cannot accept his failing body and authority. As the audience is shown the workings of his mind, Lear's aged and crippled body may be imagined as lying somewhere else, confined to a hospital bed.

Whether Lear's body is present or not, it is possible to see Lear as a metaphor of the united Europe. No longer "in his perfect mind", visibly struggling with his overpowering weakness, and growing increasingly ephemeral, Lear is the embodiment of an empire falling apart. Like Lear, Europe can be understood both ways: as a physical and quantifiable entitya geopolitical and economic union of its member states-but also, more symbolically, as an idea of unity and understanding - a cultural and ideological construct that celebrates the possibility of communication and cooperation in all its heterogeneous complexity. As Klata's production traces the disintegration of Lear, we observe Europe undergoing a crisis which some fear may destroy it ("German Business Leaders"). Lear's decision to divide his kingdom, which in Klata's production could be seen as dictated by Lear's fear of his growing weakness, or as a result of his loss of a "perfect mind", not only leads to his fall, despair and death, but also wreaks havoc all around him. Similarly, the wave of 
nationalism and right-wing extremism, the refugee crisis, terrorist threats and decisions such as Brexit, are not just factors that blur the image of the united Europe, but may have acutely devastating consequences for its existence.

Such dramatic impact of Klata's interpretation of King Lear is enhanced by the second thematic focus of the production, which is the fatal fall of sacred and absolute power. As God's anointed representative, King/Pope Lear is both a physical being and an abstract idea of unquestionable, God-like perfection. This concept is further emphasized following Grałek's death, when Lear becomes literally an abstraction, although just as powerful. Likewise, Europe can be seen as a symbol of the possibility of harmony, and a promise of such harmony and peace in the world, as long as it manages to remain united (Bruter). The fall and disintegration of that idea is, therefore, threatening in ways that are hard to imagine. The recent growth of conservative nationalisms, for example, led to the victory of right-wing parties in several European countries. Thus in Poland, the Law and Justice party (PiS) took power in 2015 with a parliamentary majority. Their extremist government has recently violated several basic premises of democracy, presenting a challenge to the European Union, and leading to serious speculations about the possibility of "Polexit".

When analysed from the perspective of the production's political implications, Klata's choice of the Catholic Church for his setting proves particularly significant. Klata claims that it was not his intention to allude to any specific pope (discussion with the director, 5 August 2015), but for Polish audiences the immediate association would be with John Paul II. The election of Karol Wojtyła, a priest from a communist country, as Pope in 1978, had such an impact, especially then, that in the Polish awareness he became a synonym of the Vatican and the quintessential head of the Catholic Church. Consequently, any other symbol of the papal figure is bound instantly to evoke "the Polish Pope". Moreover, the production focuses on an ageing authority figure, which further strengthens similarities with the exceptionally long-serving John Paul II and his declining health towards the end of his life. In the Polish context, therefore, this association adds another political dimension to the production. John Paul II has been a celebrated icon of the Polish Catholic Church, and during his life he had strongly invigorated and motivated Polish clergy and believers. The fall in mass attendance observable after his death has been accompanied by the more disturbing fact that Polish Church authorities frequently disregard, ignore or dispute Pope Francis' appeals and opinions. Klata's King Lear may, thus, also be seen as a metaphor for the fall of the Polish Catholic Church, or the foreshadowing of a possible schism, which in turn reflects some of the ideological and political divisions across Europe. ${ }^{8}$

${ }^{8}$ I am much indebted to Gemma Miller for drawing my attention to the issue of John Paul II's significance for the Polish Church, and its relation to Sinéad O'Connor's 
The evocation of Sinéad O'Connor is important in this context, too. Her famous speeches drawing attention to corruption and abuse within the Catholic Church, and especially the tearing up of John Paul II's photograph during her Saturday Night Live television performance in October 1992, are clearly to be brought to mind with the opening soundtrack "Nothing Compares 2 U". Klata typically avoids commenting on his use of popular songs in productions, but he consistently uses pop-cultural or musical references that are recognized, understood and interpreted by audiences. Those pop-cultural references always have interpretative consequences, playing on the audience's ability to make associations in all its diversity. Pink Floyd's "Comfortably Numb" for the opening of Klata's Hamlet is to be treated as a sinister statement on the "state of Denmark", while, in his Titus Andronicus, Fancy's "Slice Me Nice" that accompanies the moment when Titus feeds Tamora the pie made of her sons is morbid, but comic, incidental music. Just as Sinéad O'Connor's song is instantly recognizable in "Shanzai", her strong anti-Catholic statements were likely to be known to many audience members. In an ironic twist, the song, offering a strong statement about the counterfeit goods industry, contradicts the basic message in "Nothing Compares 2 U". Importantly, using this soundtrack in the opening dance for King/Pope Lear may also aim to call into question the legitimacy of religious authorities, especially in the light of contemporary criticism of the Catholic Church which is increasing censured nowadays for peddling a cheap pretence of spirituality.

It has to be noted, however, that most audiences would not know Fatima Al Qadiri's song, recognize the language or register the "shanzai" theme. This aspect of the production only comes into focus when its intricacies are analyzed. The association with Sinéad O'Connor, and her political statements, would be much more readily available for many audience members, at least in Europe. However, the opening sequence, and consequently the whole production, would be received differently in a different cultural context, like, for example, in Beijing, where King Lear was performed in November 2016 in Beijing People's Art Theatre as part of the commemoration of the anniversary of Shakespeare's death. Chinese audiences could realize, for instance, that "Shanzai" was sung in mock-Chinese, but might miss the political allusion to Sinéad O'Connor's anticlerical statements on television. Also, the impact of the Vatican setting for global audiences could be seen as having a more general meaning, while for the Polish ones the association would be more immediate.

Shakespeare's King Lear is not only a tragedy; it is also a very pessimistic play. Concerned with the ideas of ageing, frustration, helplessness

anti-papal manifestation. Gemma pointed out those issues as we were responding to each other papers in the "Shakespeare and/in Europe: Connecting Voices" panel at the 2017 ESRA Congress in Gdańsk. 
and gradual deterioration, it offers a bleak view of the world. As Edgar and Albany remain alive, sanity can be restored, and the kingdom reunited, making catharsis possible. Such a cleansing vision, however, is not immediately available in the play, because of the overpowering sense of loss and defeat after Cordelia and Lear die. In fact, the very question of the succession to Lear's throne is not easily resolved. Kent, Albany and Edgar are possible candidates after Lear escapes to his death, so the play's ending is marked by the sense of division on the way to restoring peace in the realm. In itself, thus, the play could be read as an interesting metaphor for the current condition of Europe, which recognizes the need to remain united, but resonates with a variety of differing voices.

Klata's King Lear, ending on the moment of Lear's death, denies us any hope for a positive resolution. Without as much as a hint that harmony and order can be restored after chaos and destruction, the production only celebrates loss and death. It cannot be claimed that the production was envisioned as a metaphorical warning for Europe's imminent future, as some of its themes became clearer in the context of events following the premiere, such as the migrant crisis, or the radicalization of nationalistic governments. It is clear, however, that politicized productions can live their own lives. In view of recent events changing the political scene of Europe, Klata's Lear has acquired a sharper focus, and a strong interpretative line. Evolving in the course of performances - a situation dramatically illustrated by Grałek's death, and subsequent changes in Lear - and resonating with dynamic contexts, such productions will be fuelled by the changing perspectives of audiences and critics. Klata's Lear, thus, while retaining the more universal aspects of an iconic image of a deteriorating mind and a weakening authority, becomes also a symbol of a much more immediate iconic notion - that of Europe struggling with its current weaknesses. The Catholic Church in the production, gloriously celebrating the appearances of strength, but shaky in the moment of transition, evokes both the past of the European Christian community, and the present of Europe's struggles with political, economic and ideological challenges, both internal and external. The fact that Klata is no longer the artistic director of Teatr Stary in Kraków in consequence of a political decision by local government following the last elections, and that some of his productions, like King Lear, are no longer performed, further stresses the radical potential and the political significance of such productions.

In hindsight, then, Klata's King Lear can be seen as a strong comment on the European, and global, state of affairs. As always in his Shakespearean productions, Klata uses many linguistic and cultural references. In Lear, apart from the pseudo-Chinese "Shanzhai" and Poor Tom's Aramaic prayer, there are other culturally-specific intrusions, like the cult hit of Bronski Beat, "Smalltown Boy", to which Edmund performs his victory dance, or the afore-mentioned 
rendition of "Sto lat" as a celebratory song to the dying Lear. The fact that those elements create the sense of a plurality of voices which are historically, geographically and politically diverse, as well as culturally specific, is not something that is necessarily crucial for the production. Many audience members would be unaware of their impact beyond the purely aesthetic or performative. However, politically-informed audiences and critics can easily recognize that, in the context of the possible crisis of European unity, it may be important to remind people of the voices which connect us.

In Lear, as in his other productions, Klata uses heterogeneous elements to create a harmonious whole. His Shakespeare speaks in many voices, but, despite that multiplicity, his Shakespeare communicates well. Similarly, Europe may be speaking in many voices and struggling with misunderstandings, and yet hope to reach common ground and communicate its sense of a plural identity. However complicated this identity may be, it is both necessary and inevitable to cherish its multiplicity and diversity, as well as the complexities of the processes that have shaped, and continue to shape it. Through the acknowledgement and appreciation of the heterogeneity of the voices that constitute that identity, we can continue to engage in constructive dialogues about our shared cultural legacy(ies), and our future. Otherwise, the bleak vision of loss that ends Klata's King Lear may become Europe's reality.

\section{WORKS CITED}

Bruter, Michael. Citizens of Europe? The Emergence of a Mass European Identity. Basinstoke: Palgrave MacMillan, 2004.

Canaris, Volker. "Peter Zadek and Hamlet." Trans. Brigitte Kueppers. The Drama Review: TDR 24.1 (1980): 53-62. 10 March 2015. 13 March 2017. $<$ http://hamletguide.com/stage/pdf/zadek.pdf $>$.

Carlson, Marvin. Speaking in Tongues. Language at Play in the Theatre. Ann Arbor: University of Michigan Press, 2006.

Cieślak, Magdalena. “'... the Ruins of Europe in Back of Me.' Jan Klata's Shakespeare and the European Condition." Studia Anglica Posnaniensia: An International Review of English Studies 50.4 (2015): 67-77.

_——. "King Lear, dir. Jan Klata-Review." Shakespeare Bulletin 34.1 (2016): 132139.

Dubois, Pierre. The Recovery of the Holy Land. Transl. Walther L. Brandt. New York: Columbia University Press, 1956.

"German Business Leaders Fear Nationalism, Refugee Crisis Will Destroy EU." Reuters. 26 December 2015. 15 November 2018. < https://www.reuters.com/ article/us-europe-migrants-germany-business-idUSKBN0U907L20151226>.

Guntner, Lawrence. "From Elsinore to Brussels: Shakespeare as Translational Discourse on the German Stage." Shakespeare Without English: The Reception of 
Shakespeare in Non-anglophone Countries. Eds. Sukanta Chaudhuri and Chee Seng Lim. Delhi: Dorling Kindersley, 2006. 156-176.

“Hyperdub Release Full Details of Fatima Al Qadiri's Asiatisch.” Fact. 4 March 2014. 13 March 2017. <http://www.factmag.com/2014/03/04/hyperdub-release-fulldetails-of-fatima-al-qadiris-asiatisch-it-features-a-cover-of-nothing-compares-2-u/>.

Klata, Jan. Discussion with the director after the performance of King Lear. Gdańsk Shakespeare Festival. 5 August 2015.

-_- Shakescene_Jan Klata at the Gdańsk Shakespeare Theatre. A special talk during the ESRA Congress in Gdańsk. 30 July 2017.

Mancewicz, Aneta. Intermedial Shakespeares on European Stages. Basingstoke: Palgrave, 2014.

- - " "Titus Andronicus (Teatr Polski)@ Teatr Wybrzeże, Gdańsk Shakespeare Festival, Poland". ReviewingShakespeare. 3 August 2013. 12 April 2015. $<$ http://bloggingshakespeare.com/reviewing-shakespeare/titus-andronicus-teatrpolski-teatr-wybrzeze-gdansk-shakespeare-festival-poland/>.

Shakespeare, William. King Lear. MIT. 16 June 2017. <http://shakespeare.mit.edu/ lear/full.html>.

Wicher, Andrzej. "In Pursuit of the 'Real Difference': A Study of the Medieval Roots of National Identity." Culture and Identity. Selected Aspects and Approaches. Eds. Suzanne Stern-Gillet et al. Katowice: Wydawnictwo Uniwersytetu Śląskiego, 1996. 104-118. 